\title{
A study of stormwater runoff quality
}

\section{Authors: William G. Characklis, P.B. Bedient, F.G. Gaudet, and Frank Roe}

This is a postprint of an article that originally appeared in Progress in Water Technology in 1979.

Characklis, W.G., P.B. Bedient, F.G. Gaudet, and F.L. Roe, "A Study of Stormwater Runoff Quality," Proceedings of the Ninth International Conference on Water Pollution Research, 10:673-699 (1978). 


\title{
A STUDY OF STORMWATER RUNOFF QUALITY
}

W.G. Characklis, P.B. Bedient, F.G. Gaudet and F.L. Roe

Department of Environmental Science and Engineering, Rice University, Houston, Texas 77001, U.S.A.

\begin{abstract}
The stormwater from four watersheds in the Houston area was monitored by an intensive sampling and analytical program over a three year period. The land use in the watersheds included undeveloped forest, developing forest, fully developed residential and mixed commercialresidential.

Chemical parameters monitored included suspended solids, oxygen demand, organic carbon, nitrogen, phosphorous, dissolved oxygen, $\mathrm{pH}$, specific conductance and chlorinated hydrocarbons. Indicator and pathogenic bacterial content were enumerated as well as aquatic and edaphic algae species. Disinfectant demand and algal bioassays were also conducted.
\end{abstract}

Relationships have been developed between stormwater runoff quality, quantity and land use in an effort to predict pollutant loads. The appearance of a "first flush" is dependent on the parameter measured and the watershed characteristics. Rainwater quality contributes significantly to stormater pollutant load, especially in urbanized areas. The modifying effect of natural biological processes on nitrogen content in the runoff and the effects of the hydrological regime on nutrient limitations has been observed. The effectiveness of storage lakes, very positive in the case of suspended solids, has been described.

\section{INTRODUCTION}

Non-point source pollution has become of greater concern due to increasingly stringent point source effluent standards and rapid development of urban areas. Urban stormwater runoff is one of the major non-point pollution sources, and planning agencies find it necessary to assess its relative importance. Since urban areas are typified by a variety of land uses, including residential, commercial and industrial as the broadest categories, determining effects of land use on stormwater quality is a potentially useful research direction. Urban watersheds of similar physiographic and drainage characterisitics in the Houston area were studied to relate runoff quality to land use.

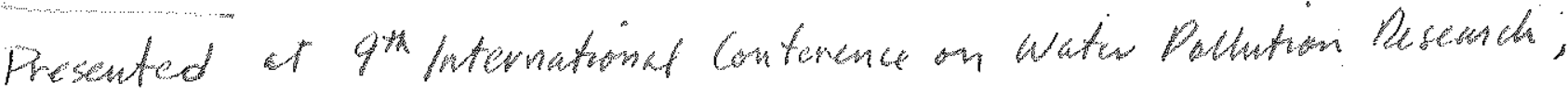

$$
\begin{aligned}
& \text { stockholm, voue } 1928 .
\end{aligned}
$$


Simulation models have been developed for management and prediction purposes regarding the effects of land use, drainage patterns, vegetative cover and storage capacity on quality and quantity of stormwater runoff. Several specialized models have been developed for simulating urban stormwater runoff. The U.S. Environmental Protection Agency has sponsored development of one such model, the Storm Water Management Model (SWMM). SWMM was used in two of the watersheds studied to predict hydrologic and water quality response. Results have been described elsewhere (Winslow et al., 1974; Diniz et al., 1975; Diniz et al., 1976).

This paper deals with the results of a massive sampling program of dry and wet weather streamflow, rainfall and lakes in four watersheds in the Houston area. The land uses included undeveloped forest, developing forest, residential, and mixed commercial-residential. Table 1 lists water quality analyses, bacterial enumerations and other investigations conducted regularly.

\section{SITE DESCRIPTION}

Stormwater quality depends on other watershed characteristics besides land use. Therefore, careful selection of study sites and/or precise delineation of watershed characteristics is imperative to producing results useful for prediction. Factors essential for source definition and comparison include geographical, meteorological and demographical information, as well as traditional land use categorization. Drainage characteristics such as percent impervious cover, watershed area, hydraulic land slope and type of stormwater drainage system can influence water quality and quantity.

Careful selection of a watershed can reduce the number of variables necessary to define causal relationships in runoff quality, therefore homogeneous land use in a watershed may be considered an advantage. Description of the four sites used in this study is summarized in Table 2. More detailed data can be found elsewhere (Characklis et al., 1976). The forest site and forest site under development are located in Woodlands, Texas, a planned community which has a projected population of approximately 120,000 by 1990 . The Westbury and Hunting Bayou watersheds are located in Houston (Fig. 1). Hunting Bayou is a developed watershed with strong industrial influences and deteriorating residential areas. Westbury. Square is a middle class residential area and was chosen because of its homogeneity with respect to land use.

\section{RESULTS AND DISCUSSION}

Dry weather water quality.

Surface water quality within The woodlands was monitored during ary periods to establish a baseline which would be useful for determining (a) the effect of urbanization on the water quality at The Woodlands in the future, and (b) immediate comparisons between runoff quality and baseflow water quality. Sampling 
TABLE 1. Water quality parameters and investigation conducted regularly

\begin{tabular}{|c|c|}
\hline Chemical & Biological \\
\hline 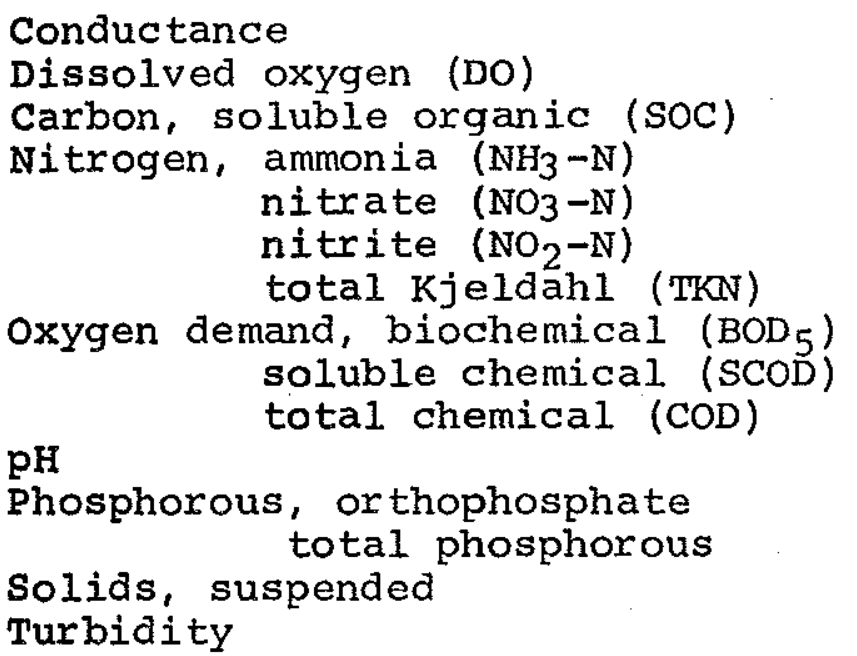 & $\begin{array}{l}\text { Coliforms, fecal } \\
\text { total } \\
\text { Fecal streptococci } \\
\text { Pseudomonas sp. } \\
\frac{\text { Salmonella sp. }}{\text { Staphylococcus sp. }}\end{array}$ \\
\hline
\end{tabular}




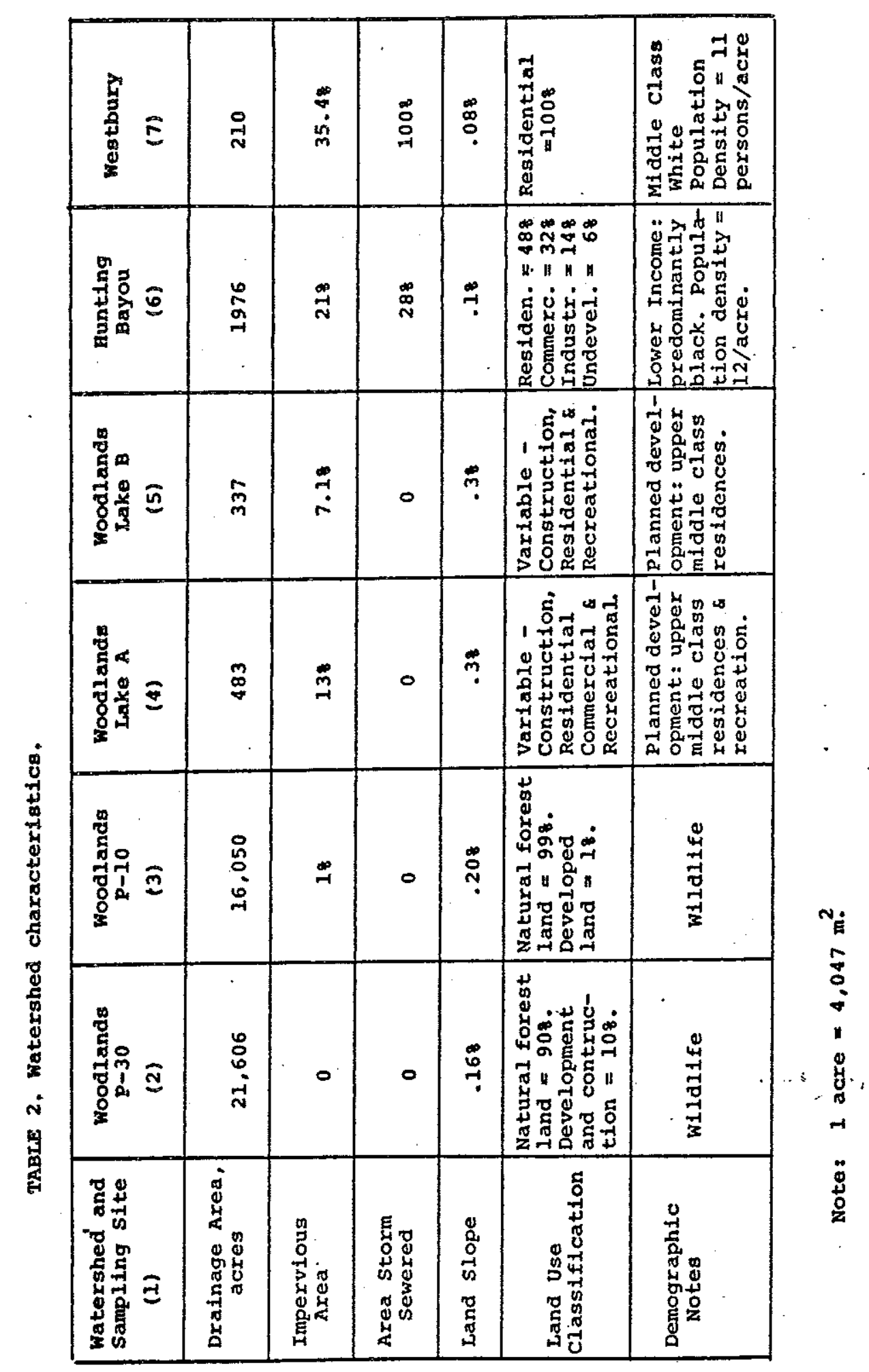




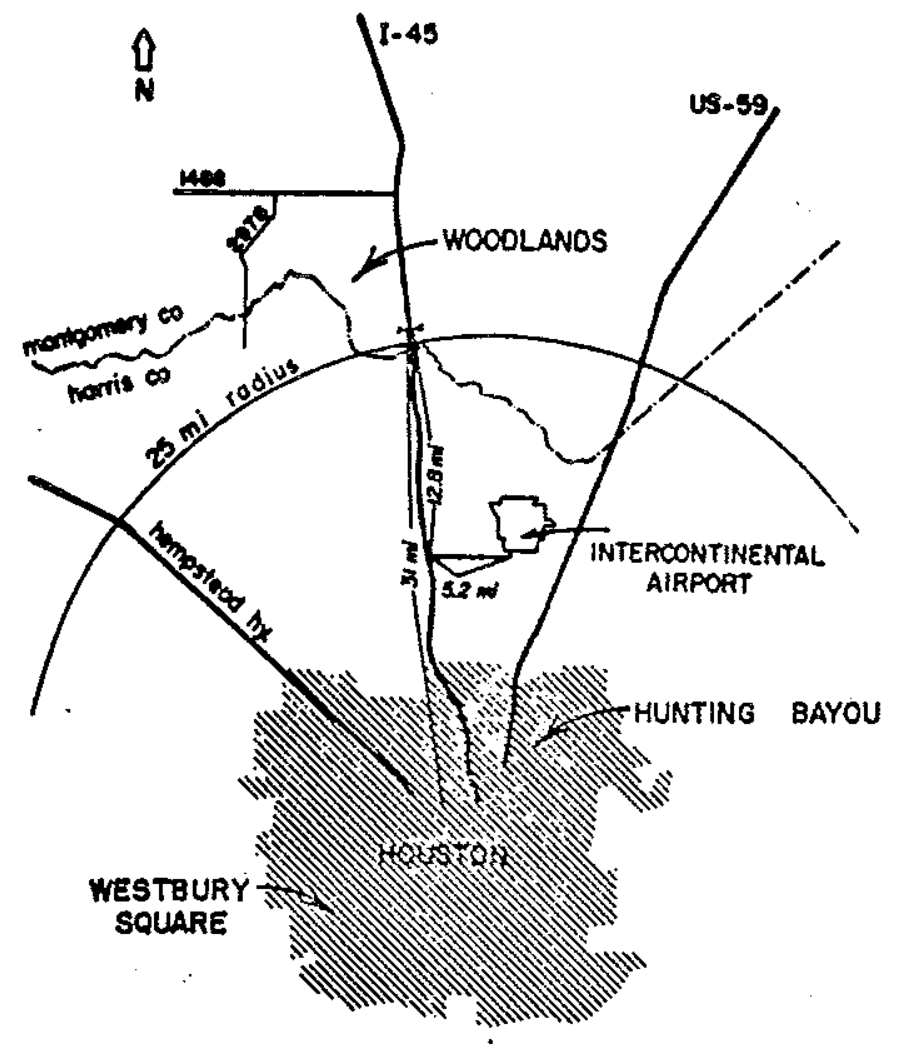

Fig. 1, Location of study sites. 
sites at The Woodlands are indicated in Fig. 2. In the Panther Branch watershed, dry weather conditions (i.e., constant stream stage) were normally established in about 4-8 days. The dry weather data is summarized in Table 3. The headwaters in the stream system are low in inorganic nutrients but significant contributions from developing areas increase concentrations below sampling site $\mathrm{P}-10$. The primary nutrient input is from the golf course immediately upstream of $\mathrm{p}-30$. The organic material consists primarily of relatively non-biodegradable leachate from decaying forest vegetation. Suspended solids increase drastically as the stream passes through developing areas where construction activity and borrow pits are located.

Westbury Square watershed has no dry weather flow and Hunting Bayou is essentially stagnant during dry weather so no results are indicated.

Storm event summary

Data characterizing hydrological, physical, and chemical qualities of 43 distinct runoff events resulted from 17 selected rainfall periods with streamflow being sampled simultaneously at one to four of the sample sites. A summary of hydrological data for the more significant storms is presented in Table 4 . A summary of physical and chemical water quality data is presented in Table 5 and includes mass load and flow-weighted mean concentration for each parameter. Mass load refers to the total mass of constituent passing the sampling point during the event. All water quality samples are representative of total streamflow volume including baseflow. In most cases, runoff equalled total streamflow and samples can be considered representative of runoff. For low runoff events, water quality could be influenced by baseflow.

Rainfall quality. Air quality contributes to water quality through rainfall or dry fallout, even to the extent of pollutants traveling from industrial or agricultural regions to be deposited in undeveloped regions. Samples were collected in Houston and the Woodlands to assess the relative contribution of rain to surface water quality. Results summarized in Fig. 3 indicate a substantial nutrient and organic load at both sites and compares the rainfall quality to the runoff quality. The organic content of Woodlands rainfall has been attributed to vegetative emissions while Houston air quality is severely" affected by automotive emissions and other industrial activities.

The data also suggests that $\mathrm{NH}_{3} \mathrm{~N}$ in rainwater is modified to a large extent in the forested area by plant metabolism. This problem is of concern with regard to lake eutrophication processes at The Woodlands where phosphorous limits algae growth during dry weather and nitrogen during wet weather (Ward and King, 1976). As development continues, rainfall will bring increasing nitrogen to the surface waters causing further lake enrichment.

Comparison of runoff to domestic wastewaters. Table 6 compares runoff quality to treated and untreated domestic wastewater. 


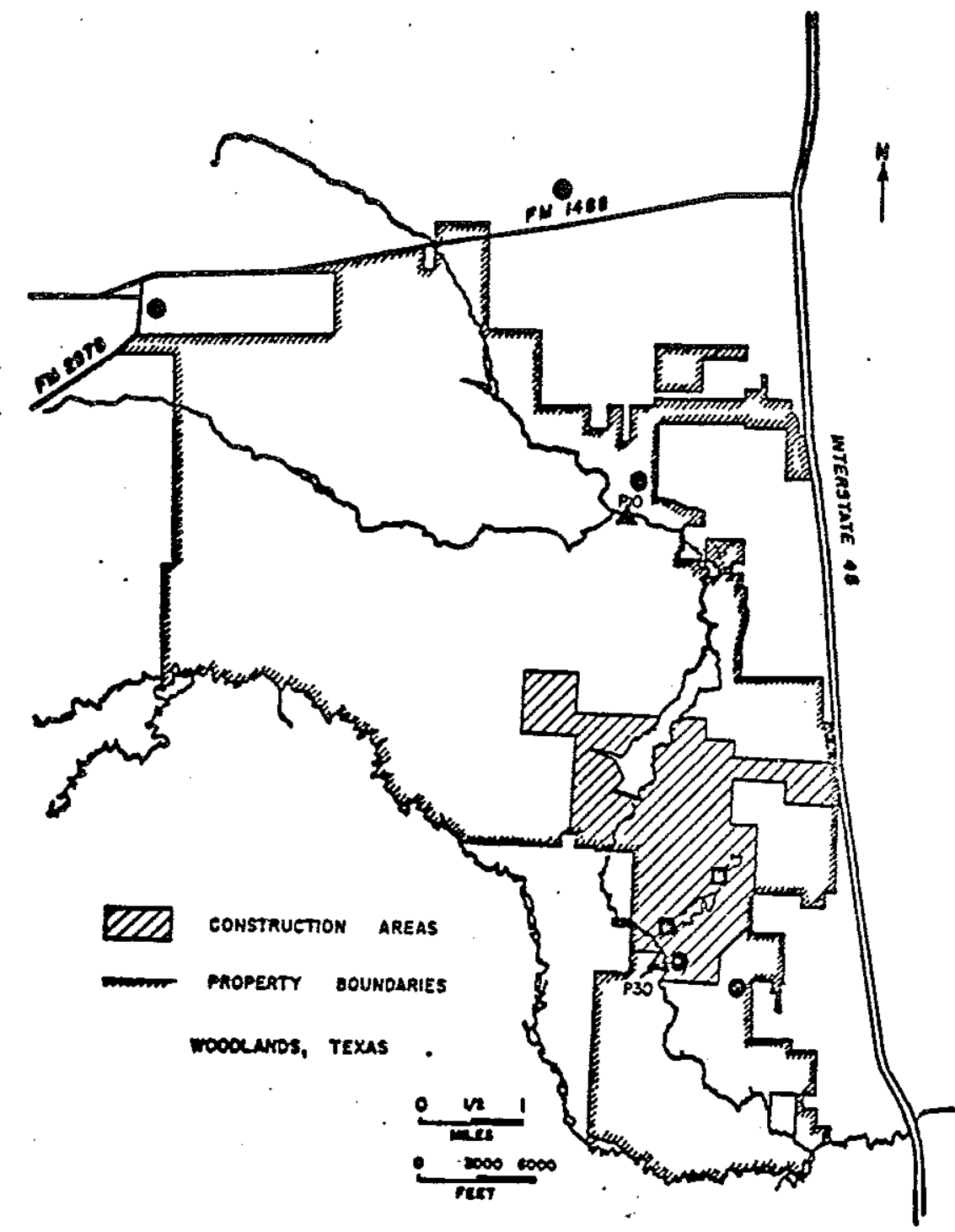

- lake sampling sites

" $\triangle$ STREAMFLOW MONITORING SITES

- rainfall recorders

Fig. 2. Location of sampling sites and rain gages. 


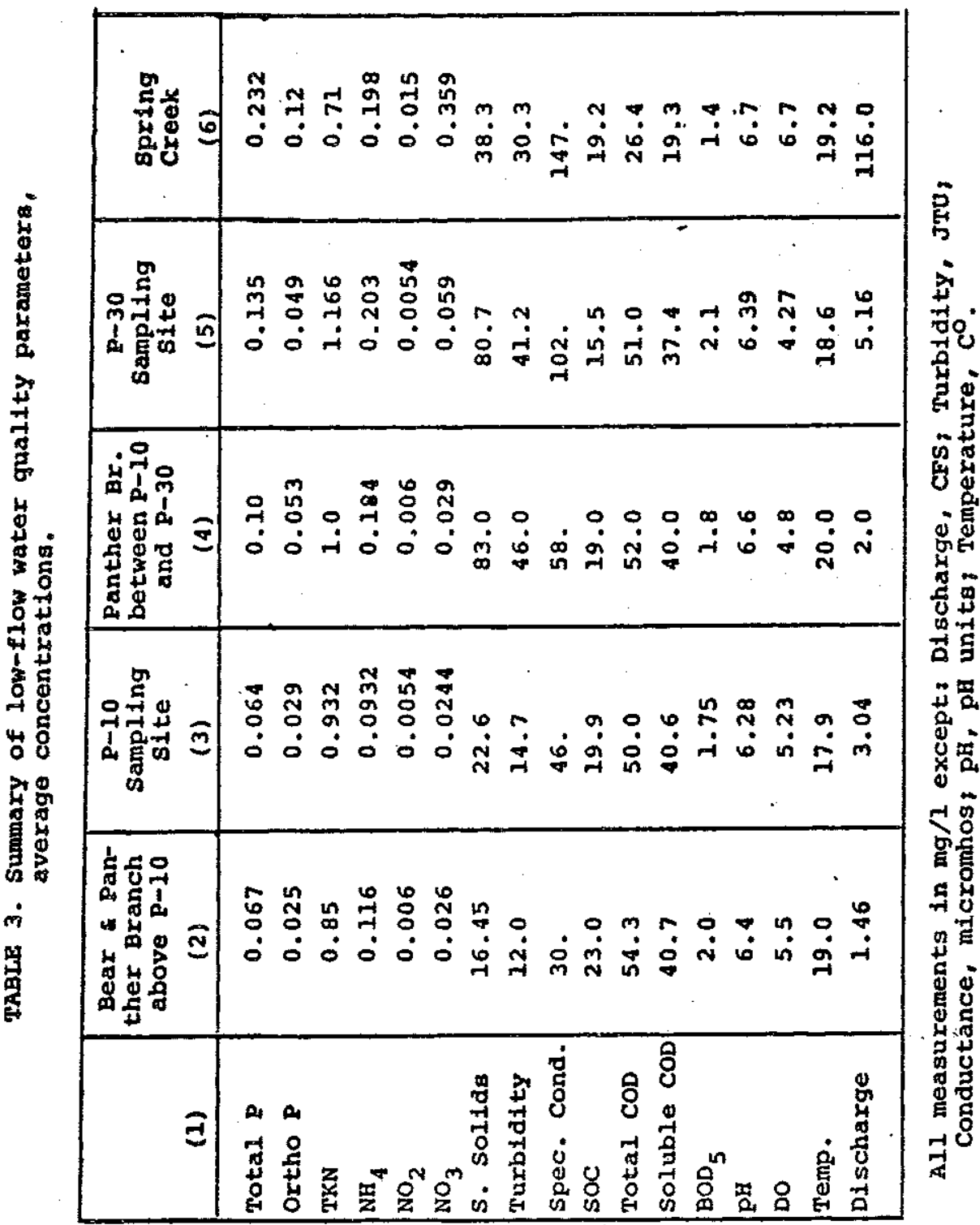




\begin{tabular}{|c|c|c|c|c|c|}
\hline 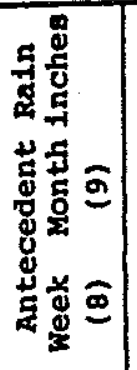 & $\begin{array}{cc}0 & \stackrel{m}{0} \\
\dot{\infty} & \dot{m} \\
& \\
\stackrel{n}{0} & \stackrel{n}{\sim} \\
\dot{-i} & \stackrel{-}{i}\end{array}$ & $\begin{array}{l}\stackrel{m}{n} \\
-1 \\
-1 \\
0 \\
0 \\
0\end{array}$ & 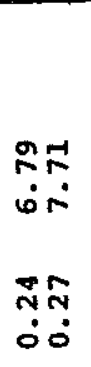 & 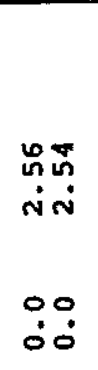 & 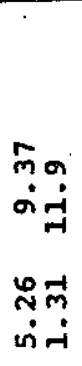 \\
\hline 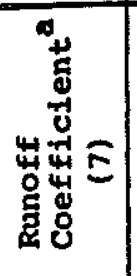 & 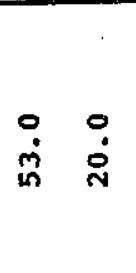 & $\stackrel{0}{\stackrel{\leftrightarrow}{2}}$ & $\begin{array}{l}00 \\
\dot{m} \dot{\circ}\end{array}$ & 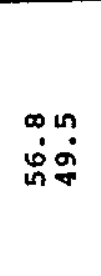 & 品品 \\
\hline 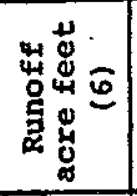 & $\stackrel{0}{:} \stackrel{\infty}{\dot{i}}$ & $\begin{array}{l}\text { D. } \\
\text { जू } \\
\sigma\end{array}$ & $\begin{array}{l}00 \\
\dot{\infty} \underset{\sim}{\sim} \underset{\sim}{\mathbb{N}} \\
\underset{\sim}{\infty}\end{array}$ & 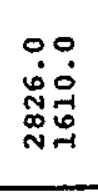 & 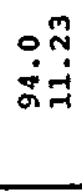 \\
\hline 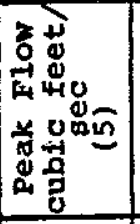 & $\begin{array}{ll}0 & 0 \\
\dot{0} & \dot{0} \\
\stackrel{0}{*} & \end{array}$ & $\stackrel{0}{\dot{0}}$ & $\begin{array}{l}\dot{0} 0 \\
\dot{\sim} \dot{0} \\
\text { mind }\end{array}$ & $\begin{array}{l}00 \\
\therefore 8 \\
07 \\
07\end{array}$ & 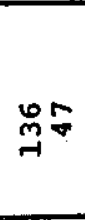 \\
\hline 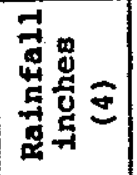 & $\begin{array}{ll}\stackrel{n}{0} & \stackrel{n}{\sim} \\
\dot{N} & \ddot{0}\end{array}$ & $\begin{array}{l}\dot{0} \\
\dot{m}\end{array}$ & 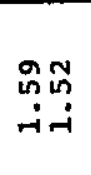 & $\stackrel{\mathscr{m}}{\dot{N}}$ & מू心 \\
\hline 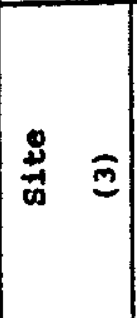 & 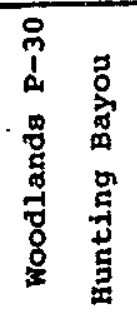 & 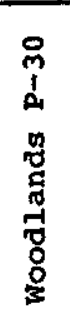 & 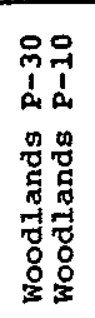 & 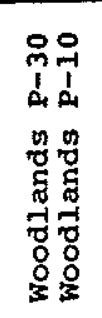 & 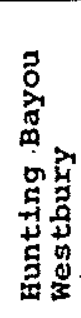 \\
\hline 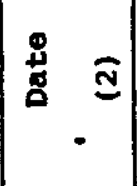 & 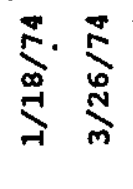 & 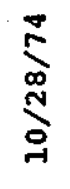 & 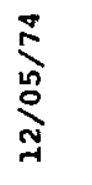 & 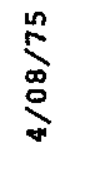 & $\frac{n}{\infty}$ \\
\hline$-\Xi$ & $H m$ & 0 & $n$ & 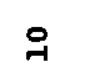 & $\mathcal{ユ}$ \\
\hline
\end{tabular}




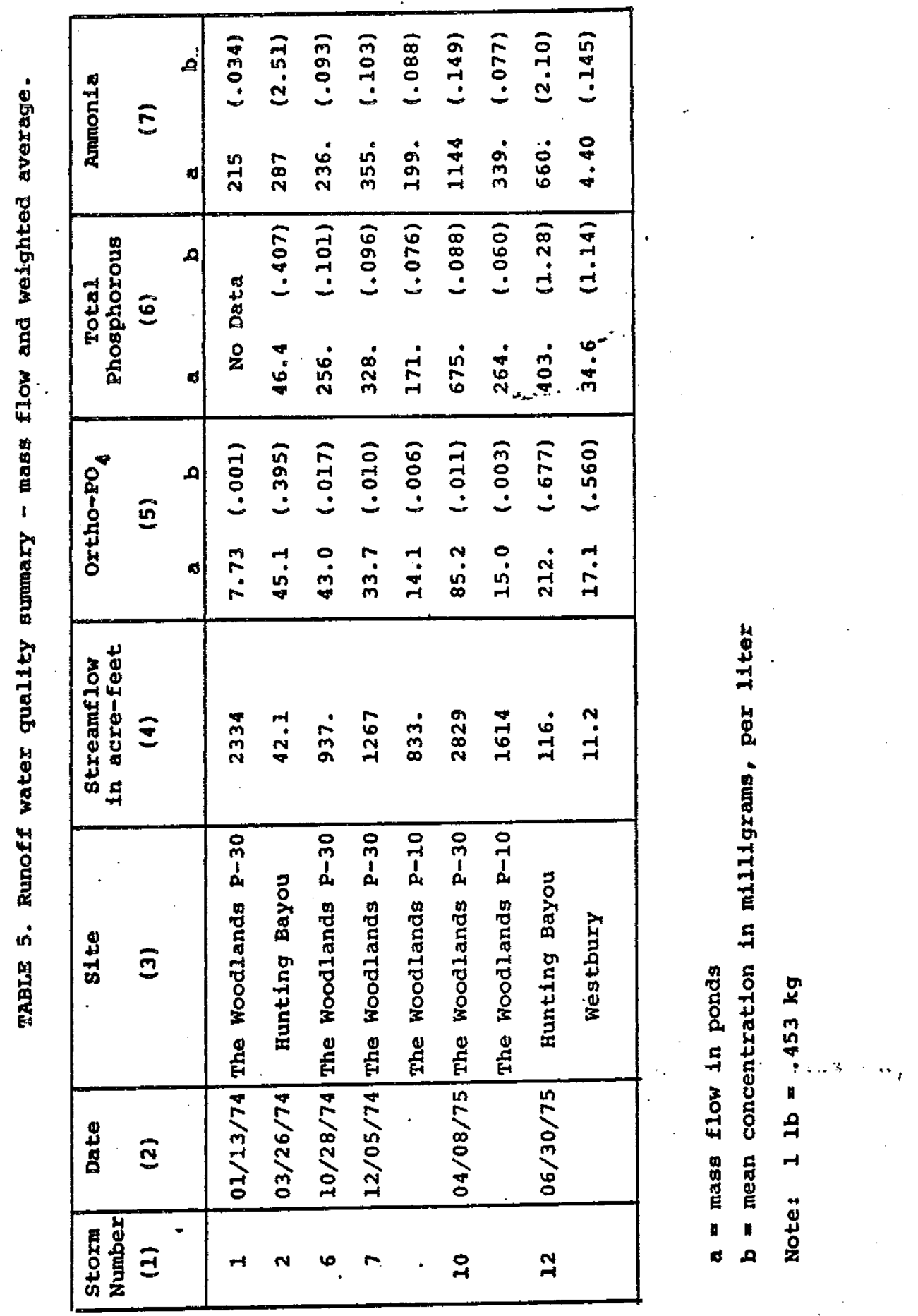




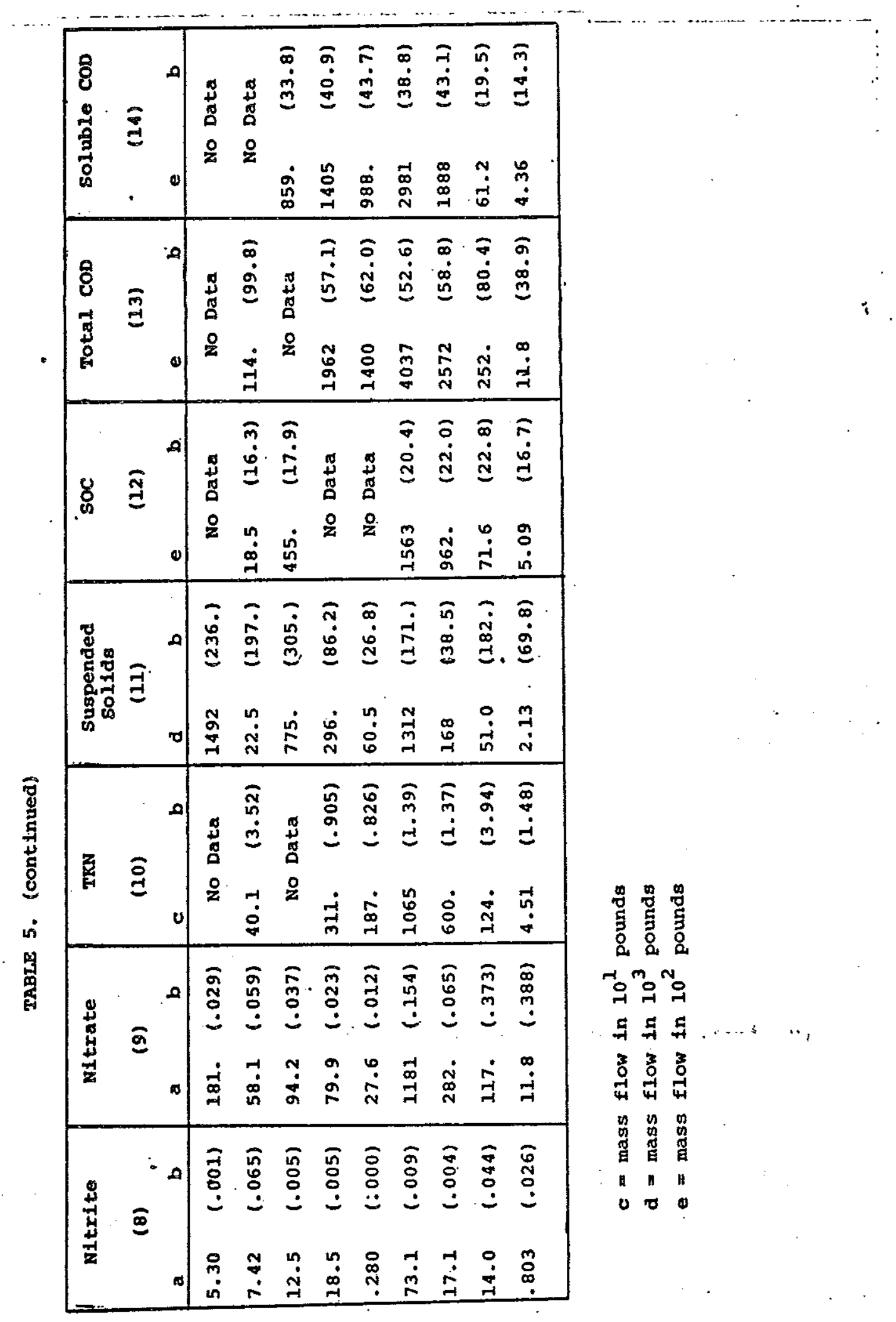




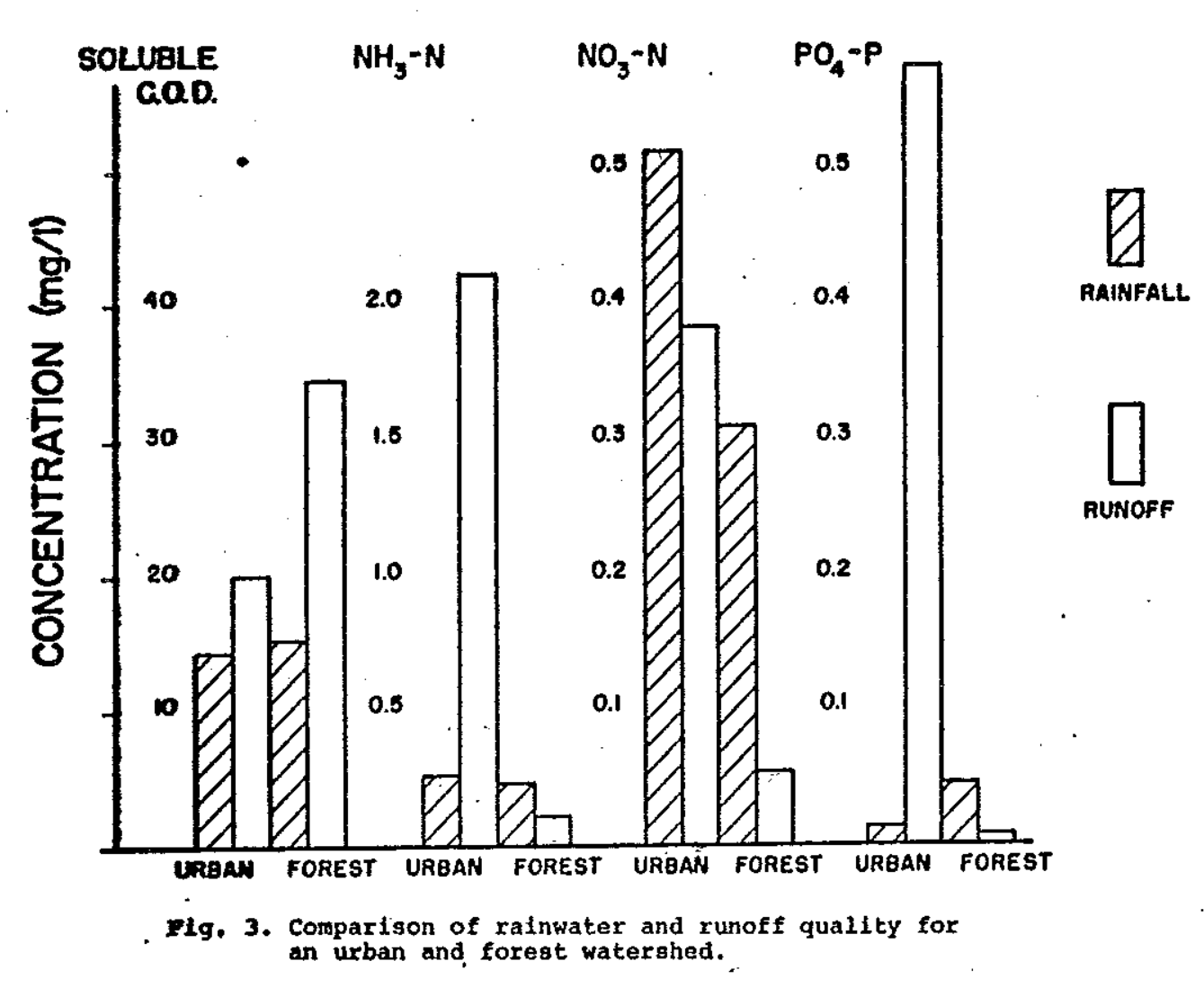




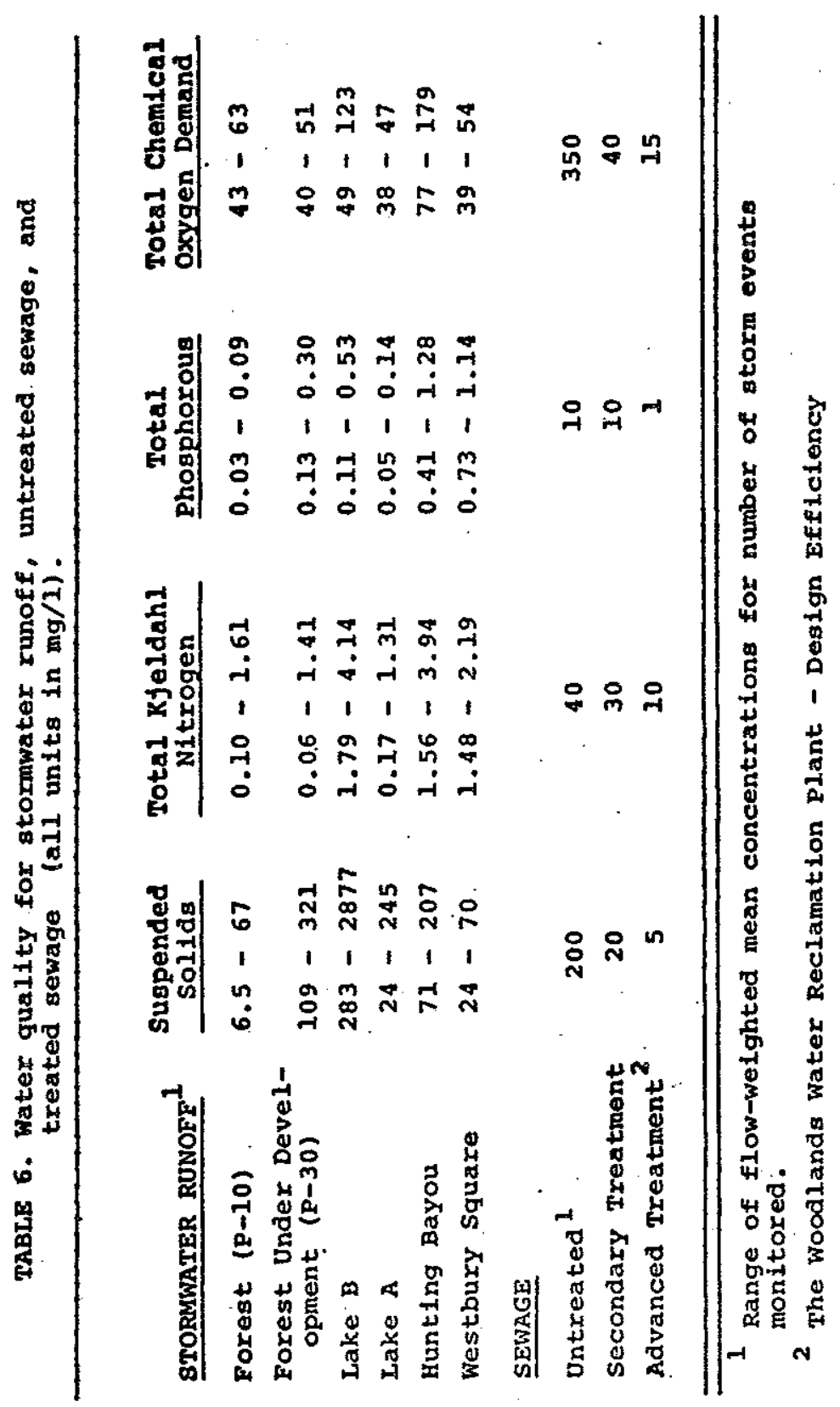


Runoff is significantly more dilute than untreated wastes except for suspended solids at $\mathrm{p}-30$, reflecting the intense construction activity during the study period. Advanced treatment can'reduce organic and solids content below that in runoff but nutrients still remain higher. Samples of untreated and chlorinated secondary wastewater were obtained from two Houston sewage plants for bacteriological examination. The data obtained is compared to the bacteriological data from stormwater runoff in Table 7. Urban stormwater contributes more microorganisms than chlorinated secondary effluent.

Temporal variations in runoff quality

A pollutograph is a plot of "pollutant" concentration as a function of time during a storm event. Temporal variations of this type are important since they may significantly influence the impact of stormwater runoff and, consequently, methods to con-. trol the adverse effects on receiving waters. Five generalized patterns emerged in this study (Fig. 4).

"First flush" (Fig. 4a) was observed most frequently in the urban watersheds with suspended solids and nutrients ( $N$ and $P$ compounds). Harned (1977) has used dimensionless cumulative analysis (Marsalek, 1976) to demonstrate the magnitude of the first flush in the watersheds. Figure 5 compares suspended solids runoff characteristics from $\mathrm{p}-10, \mathrm{p}-30$ and Hunting Bayou and indicates the effect of intense construction activity at $\mathrm{P}-30$.

Specific conductance in the baseflow at P-10 is high and stormwater inflow provides dilution as indicated by Fig. 4b. An analysis of nitrate at $\mathrm{P}-10$ and $\mathrm{P}-30$ indicates dilution effect at $\mathrm{P}-10$ and first flush effect at $\mathrm{P}-30$ caused by intensive fertilization of an adjacent golf course. The dilution pattern also exists for many parameters in urban streams where wastewater, treated or untreated, comprises the greater part of the baseflow.

Organic content (SOC and COD) generally increased as runoff progressed (Fig. $4 \mathrm{c}$ ) at $\mathrm{P}-10$ and $\mathrm{P}-30$. Streamflow contributions from interstitial water and bank storage flow is greatest late in runoff and could account for the pattern when enriched by contact with soils serving as an organic carbon source, such as those in the pine forest region. Increased reaeration at greater stream flows accounts for a pollutograph which is congruent with the hydrograph (Fig. 4d).

In the undeveloped forest watershed ( $\mathrm{P}-10)$, several parameters (including $\mathrm{pH}, \mathrm{NH}_{3}-\mathrm{N}, \mathrm{NO}_{2}-\mathrm{N}$ and solubled COD) remained relatively constant throughout the storm event. This pattern was not routinely observed in the other watersheds where drastic alterations in land use have occurred.

Effect of land use on runoff quality Total load of various pollutants (Ibs/acre) was plotted against total runoff (inches) for all storm events and watersheds. Regression lines and associated correlation coefficients are shown in Figs. 6 and 7 for several parameters. Correlation coeffi-. cients are generally greater than 0.9 with a few unsatisfactory cases. The urban watersheds produce higher pollutant loads in almost every parameter. Suspended solids produce one exception explainable by the construction activity at $\mathrm{p}-30$. Organic con- 


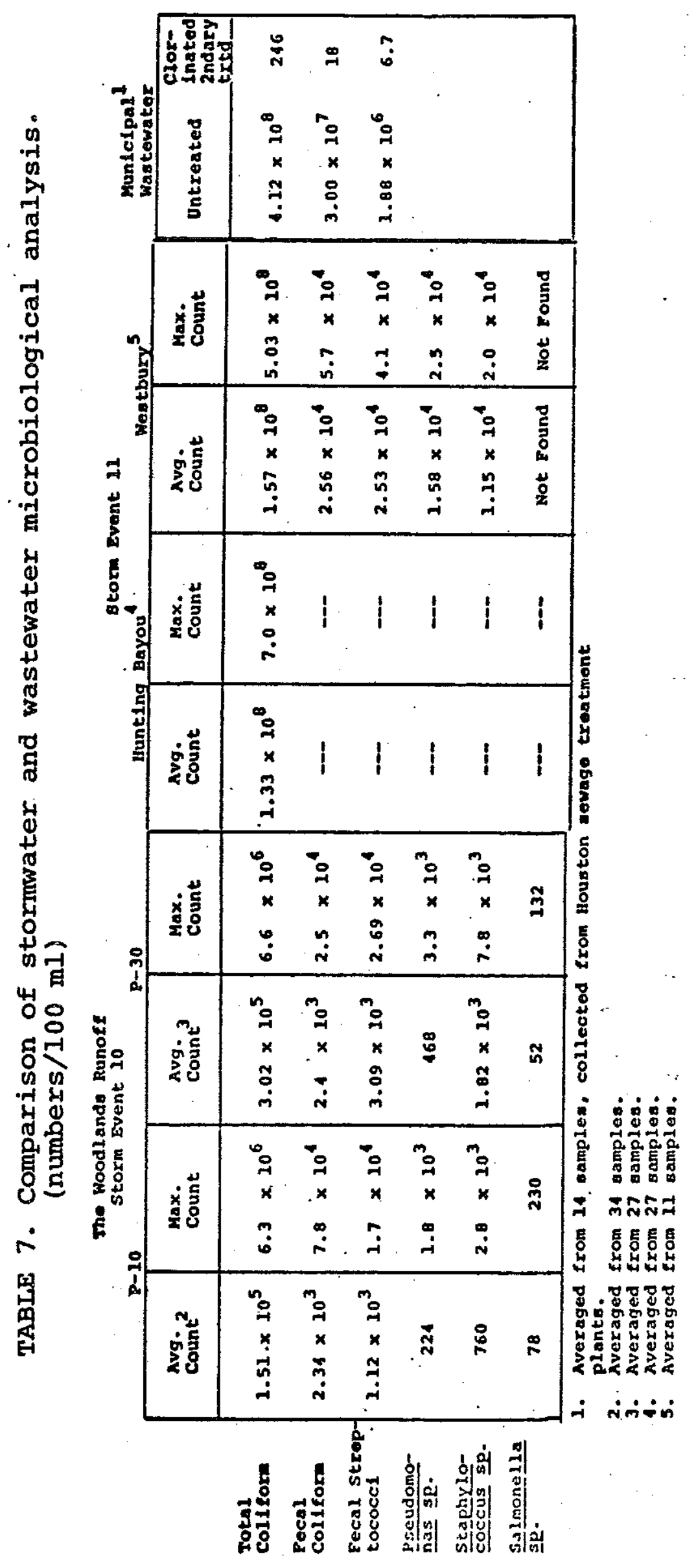




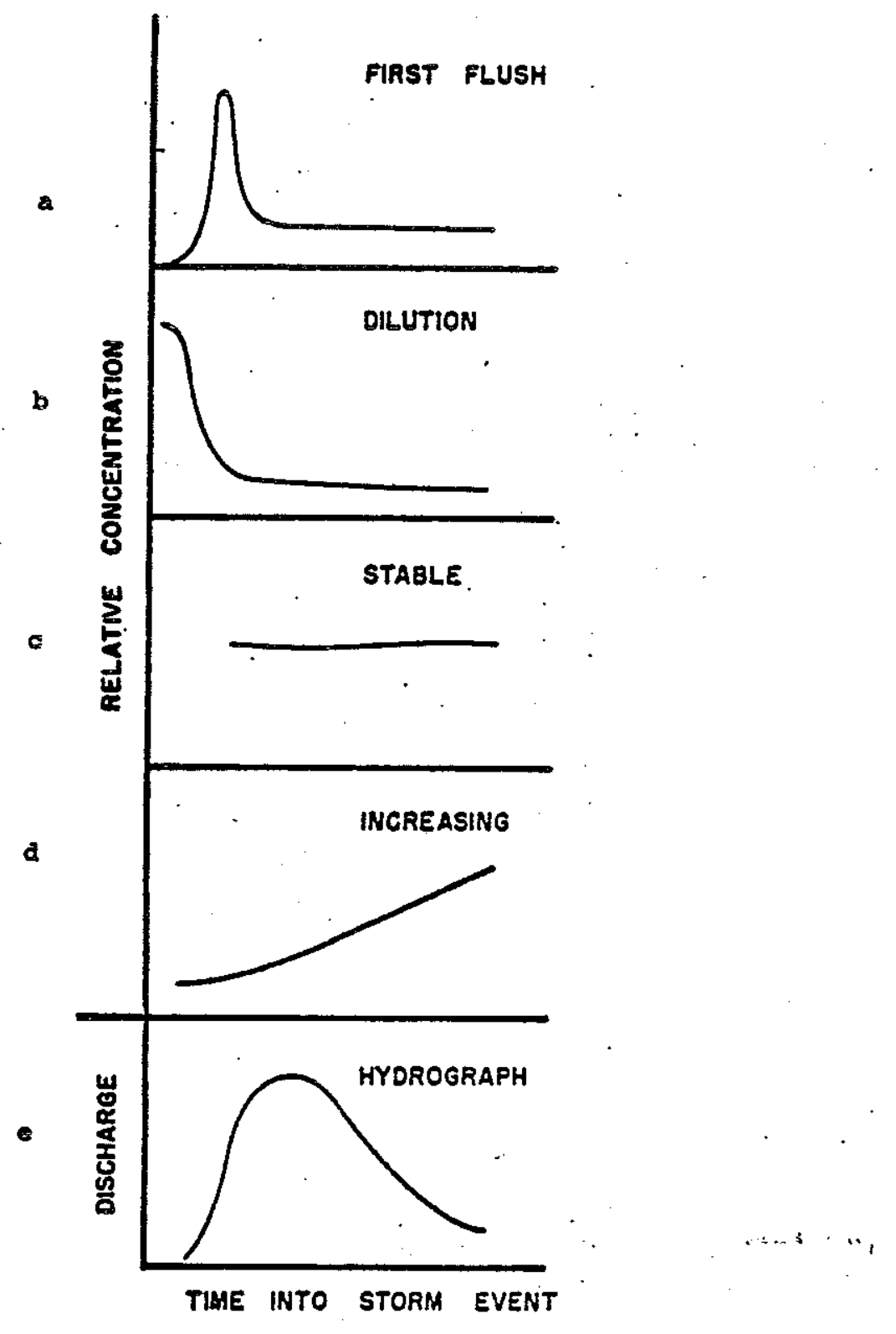

Fig. 4. Generalized pollutographs observed for stormwater parameters. 

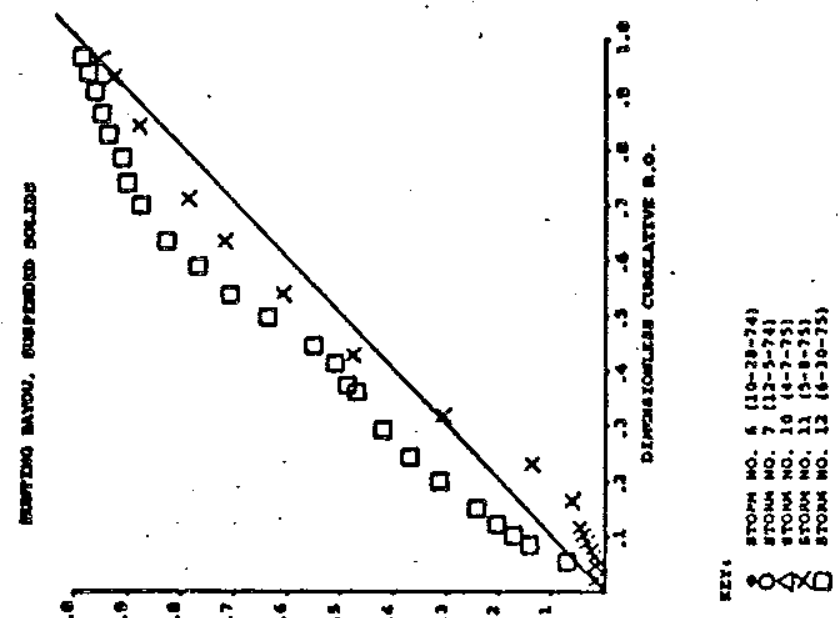



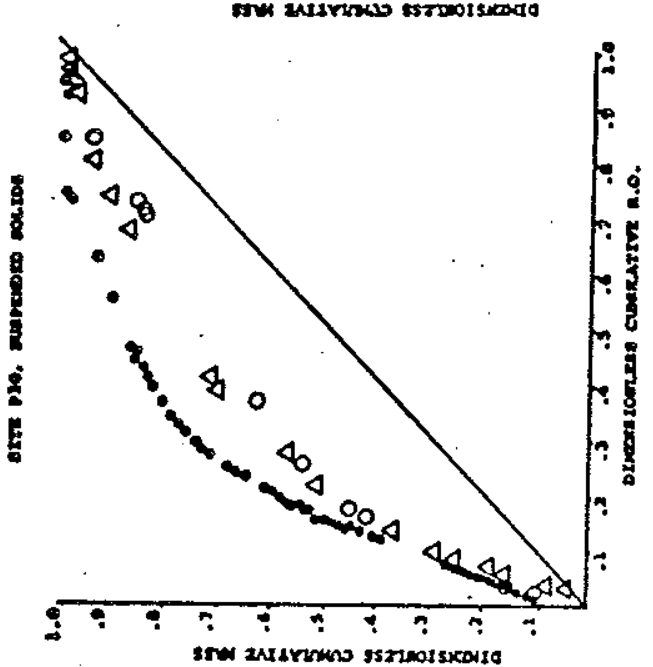

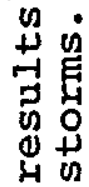

ด

ติ

겅

究

.

+ +

옥

an

行

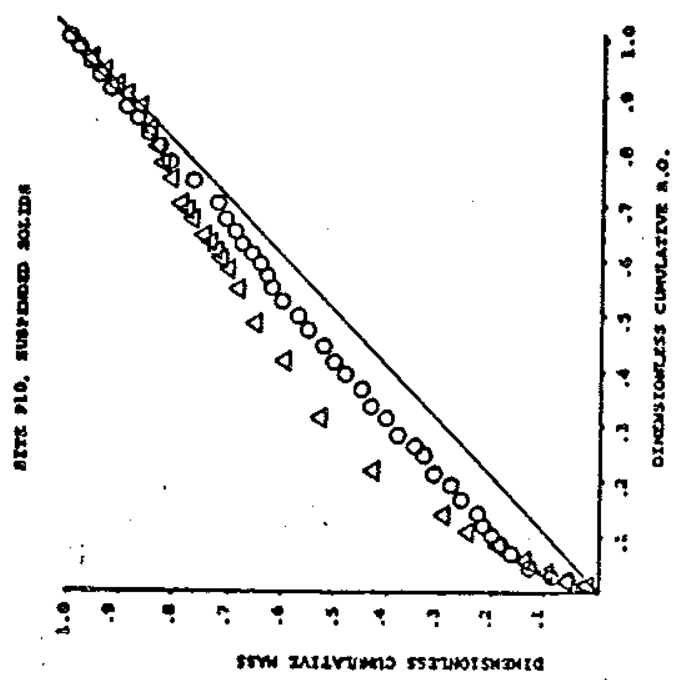

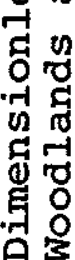

$-\$ \quad \cdots$

เก

㝗 

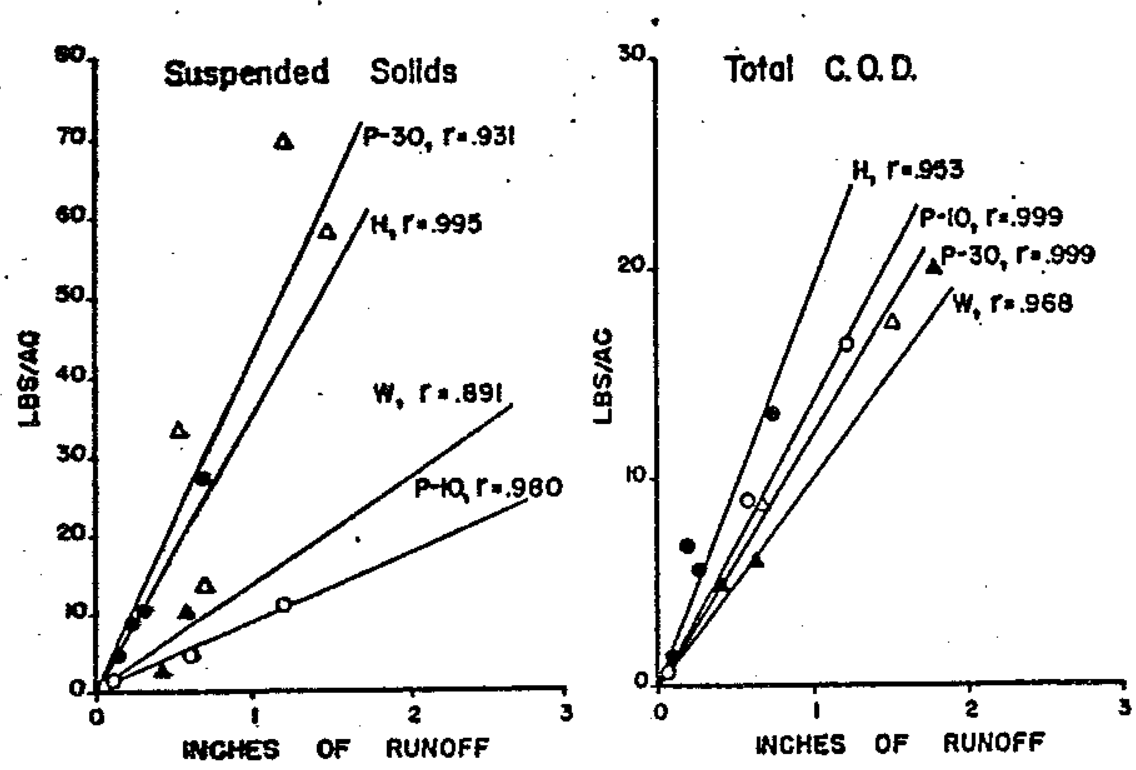

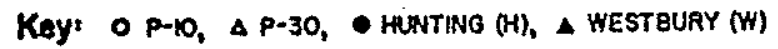

Eig. 6. Load-runoff relationships for suspended solids and total $C O D$ as related to the watersheds atudies ( $r$ is the correlation coefficient).
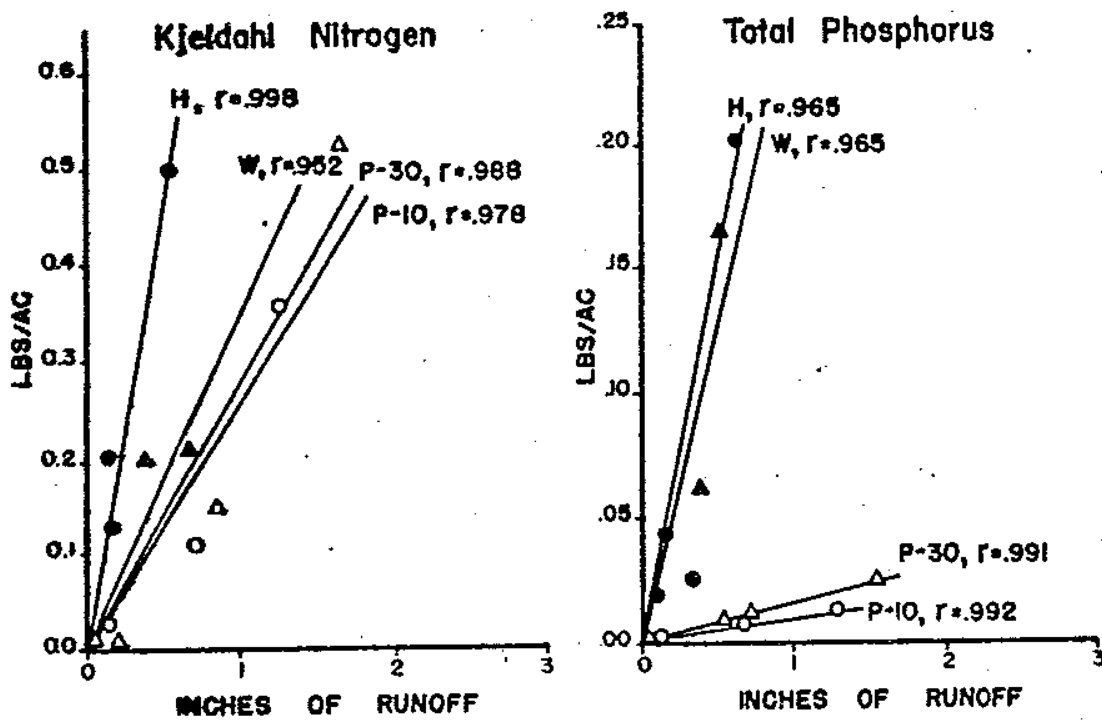

Key: O P-10, $\triangle$ P-30, - MUNTWO (H), $\triangle$ WESTBURY (M) $+\cdots$

Ftg. 7. Load-runoff relationships for xjeldahl nitrogen and total phosphorus. 
centrations are also higher in the forested watersheds because of leachate from vegetation and the absence of wastewater in the'urban streams.

One important characteristic of the watersheds is percent imperviousness which has been used by others (Dannenbaum Engineering Corp. and Espey-Huston and Assoc., 1977) to determine predictive models. Figure 8 indicates the load-runoff relationships for ten watersheds including the ones of major concern in this paper. The slopes of these lines have units of concentration and represent the "average concentration" of the parameter in the runoff from the respective watershed. Figure 9 indicates the relationship of this "average concentration" to percent impervious area in the watershed. Although correlation is not high, results do indicate that percent impervious area is an important variable to consider in any predictive model.

Davis et al., 1977, produced a potentially useful comparison between watersheds with respect to bacteriological content through the use of the fecal coliform-fecal streptococci ratio (FC/FS). FC/FS $Z 4$ suggests the presence of human wastes, FC/FS between 2 and 4 human wastes mixed with other sources and FC/FS below 0.7 a predominance of warm-blooded animal waste other than human. Log (mean FC) for storm events, dry weather flow and domestic wastewater is plotted against $\log$ (mean FS) in Fig. 10. FC and FS numbers are greater in Woodlands stormwater than in the dry weather flow of Panther Branch, however the FC/FS remained constant. The Westbury stormwater data indicated similar ratios. Samples from Lakes $A$ and $B$, which impound water in the $\mathrm{P}-30$ watershed, display significantly lower FC/FS indicating a possible beneficial effect from storage. No significant difference could be detected between chlorinated wastewater and runoff except at Lakes $A$ and $B$ where bacteriological water quality was better.

Impoundment of stormwater runoff

The man-made lake systems at The woodlands will serve as recreation centers, wildlife preserves, irrigation, and storage for stormwater runoff. The Lake Harrison system, consisting of two lakes ( $A$ and $B$ ) separated by a six ft. waterfall, was monitored during this study. To implement a continuous flow over the connecting waterfall, the smaller, upstream lake (B) is constant volume. In dry weather there is no streamflow into the lakes and the water level in Lake $B$ is maintained by recirculating water from the lower lake, Lake $A$, or by the inflow of tertiary treated wastewater. When the watershed is fully developed, wastewater flow will be approximately $6 \mathrm{~m} \cdot \mathrm{g} \cdot \mathrm{d}$. and recirculation will be unnecessary. During wet weather, Lake B receives stormwater runoff and serves as a sedimentation basin for the 337 acre watershed. Lake A is a variable volume lake to be used for noncontact recreation. Lake discharge is controlled by an outlet box.

For a year of average rainfall, The Woodlands Wastewater Reclamation Plant will comprise $75 \%$ of the flow through the lake system. Design effluent quality for the plant is indicated in Table 6 and suggests that the lakes will contain relatively clear waters with elevated nutrient levels compared to the dry weather surface quality existing presently. Lake detention time during dry wea- 


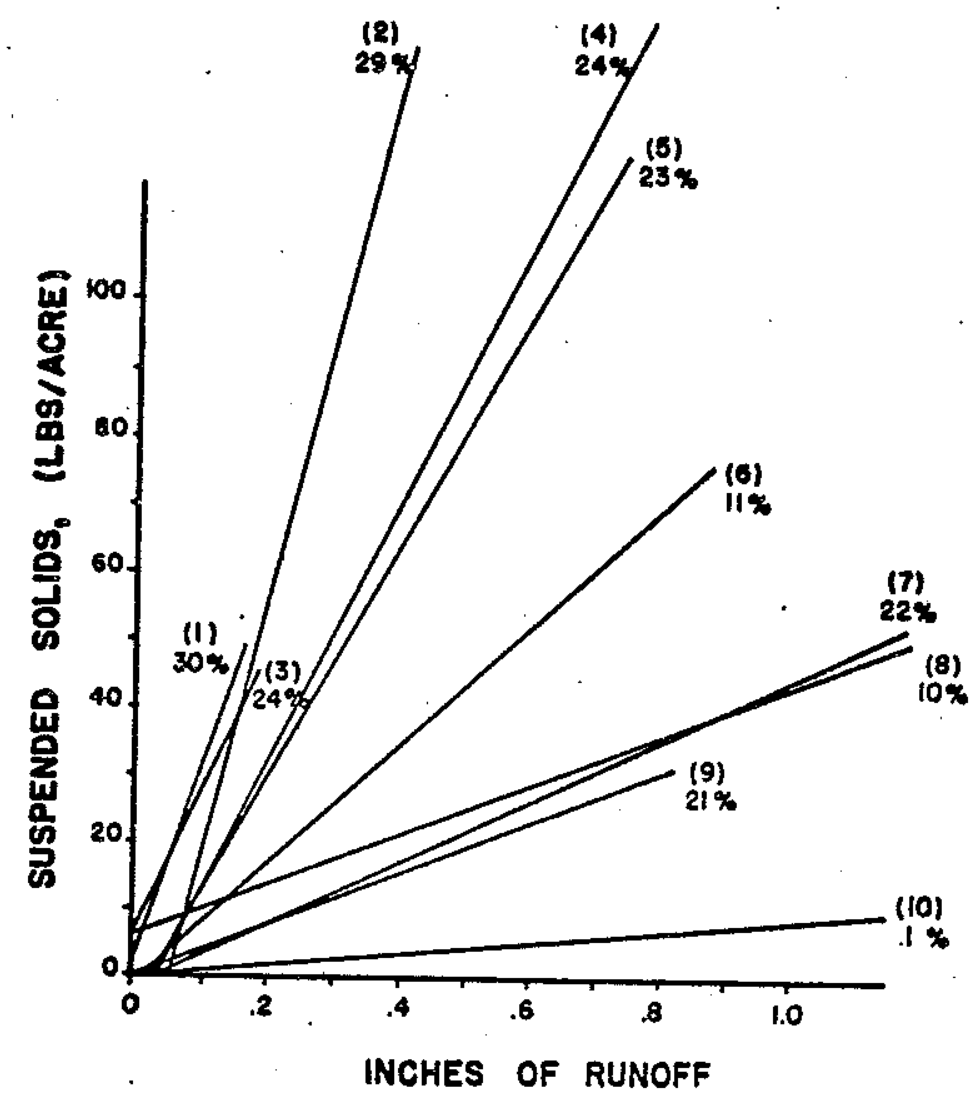

Fig. 8. Load-runoff relationships for ten watersheds, with indicated percent impervious areas (* denotes watersheds in the Houston area). 


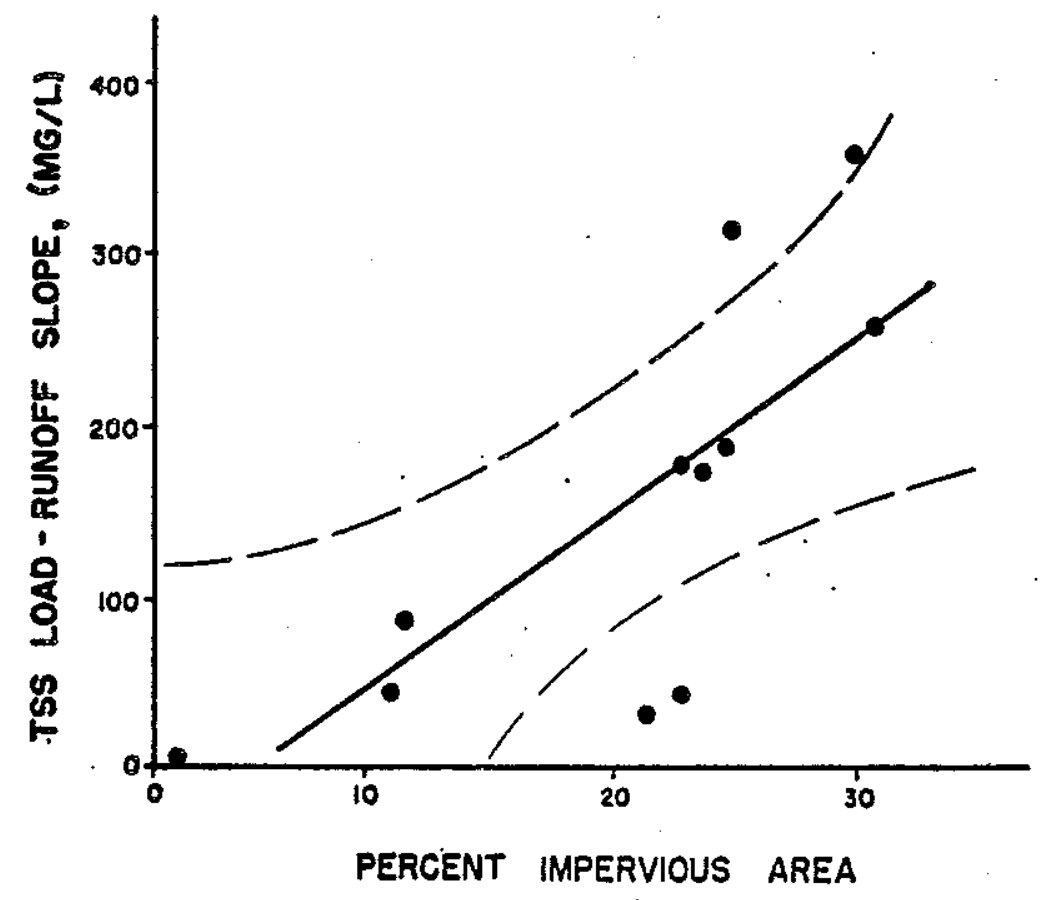

Fig. 9. Regression of percent impervious watershed area with load-runoff slopes (95\% confidence limits - dotted line, $r^{2}=.547$ ). 


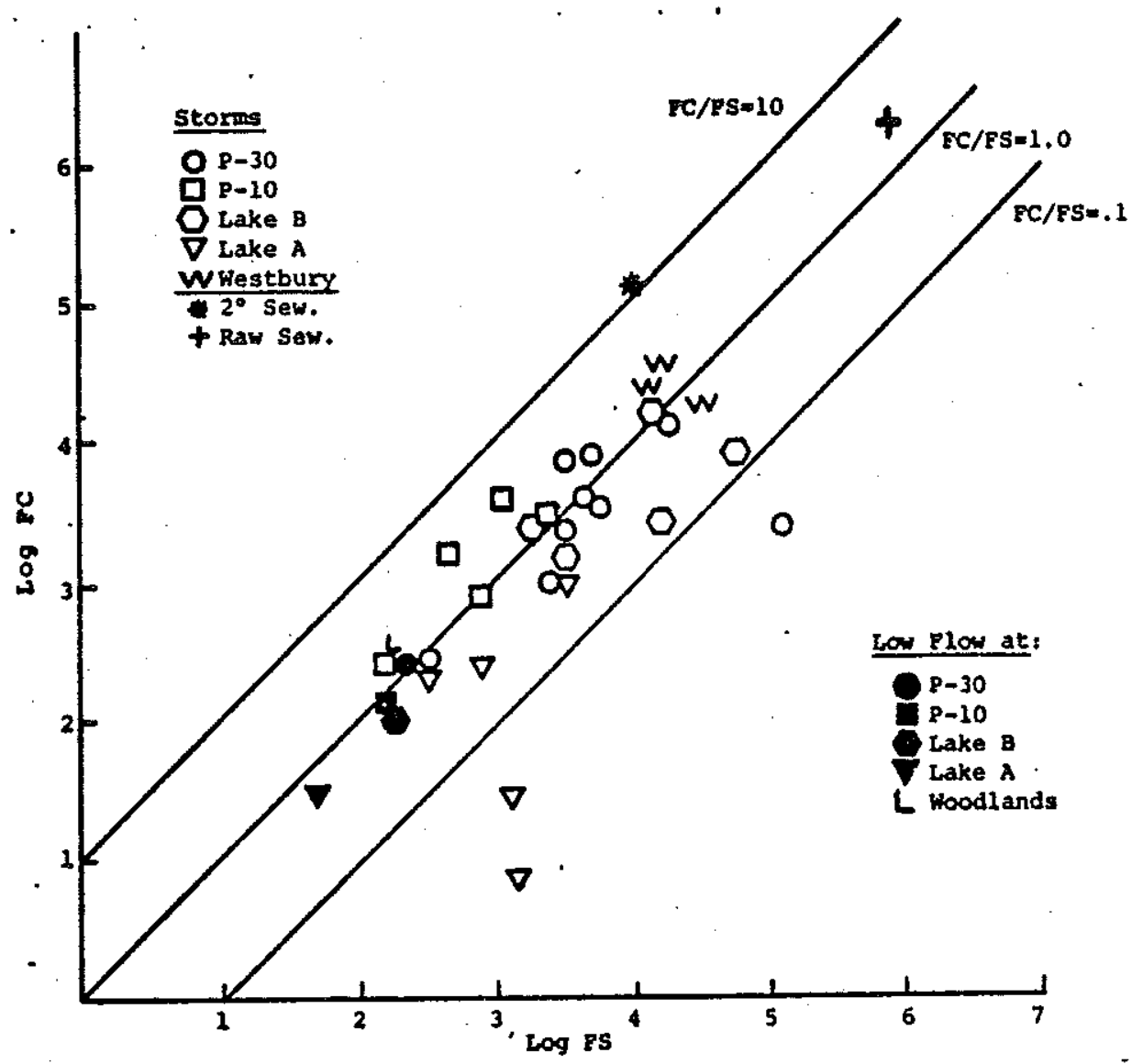

FIg. 10. Scalar approach to FC/FS patterns in different land use areas. 
ther will be approximately six days when the treatment plant is at full capacity. The lake system is shown in Fig. 2.

Effect on water quality. Table 8 compares flow weighted mean and maximum concentrations for runoff entering and leaving Lake Harrison during the storm of April 8, 1975. Results indicate that the effluent was nutrient enriched compared to the influent despite the absence of wastewater inflow. Three possibilities exist:

1) Unmeasured runoff from the fertilized area adjacent to the lakes

2) Direct precipitation

3) Quality of the water impounded in the lakes prior to the storm event.

A first flush was evident during storm events and therefore, $(\dot{3})$ seems to be the logical reason.

The lakes have proven very effective in minimizing the release of sediment eroded from construction occurring in the watershed. A good illustrative example is afforded by a storm that occurred on April 8, 1975. The suspended solids pollutograph for inflow and outflow is presented in Fig. 11 and indicates a reduction in the maximum concentration from $2660 \mathrm{mg} / 1$ to $356 \mathrm{mg} / \mathrm{l}$. The total load was reduced from 160 tons to 31 tons, an $80 \%$ reduction in solids. The reduction in lake volume was less than 0.18 if the solids compact to $80 \mathrm{lb} / \mathrm{ft}^{3}$. Therefore, the lakes are effective in reducing the solids load that enters Panther Branch. This trend in sediment removal was also observed for several other storm events.

\section{CONCLUSIONS}

Final results from the three-year stormwater study at The Woodlands yielded significant relationships between stormwater quality and land use, runoff quantity, storage capacity, and rainfall intensity. Temporal variations in runoff quality were observed to follow five generalized patterns. The imperviousness factor of land use was found to be most important for determining pollutant loads. Lake storage was found to be very effective in controlling sediment discharge.

Acknowledgements

The authors gratefully acknowledge the Environmental Protection Agency, Storm and Combined Sewer Technology Branch, The Woodlands Development Corporation, and the City of Houston, Water Pollution Control Department for financial support. Messrs. Richard Field and A.N. Tafuri (EPA) and E.N. Quevedo (City of Houston) have provided valuable guidance. 
TABLE 8. Sumary of water quality parameters for sites Lake $A$ and Lake B during the April 8, 1975

stora event.

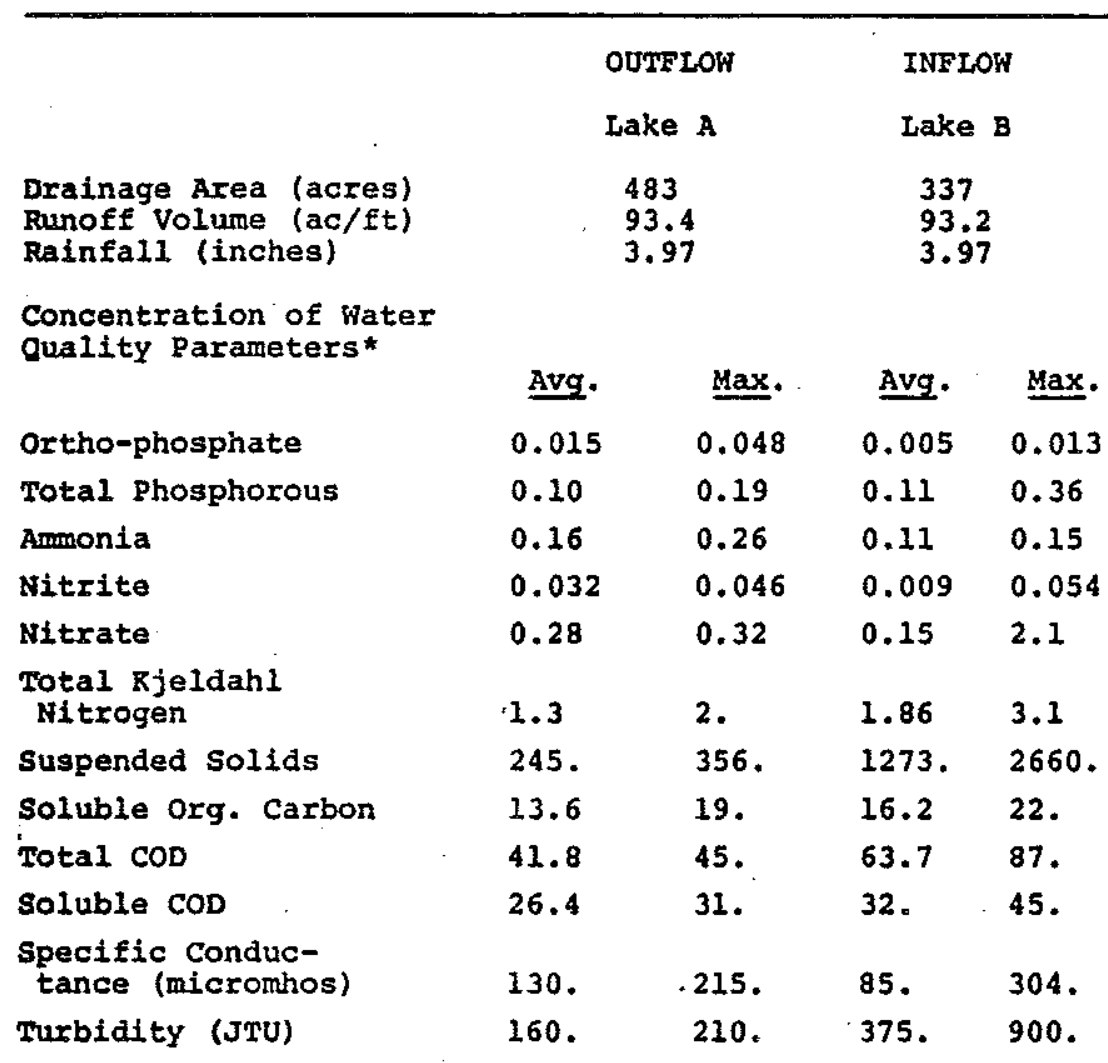

* All concentrations in $\mathrm{mg} / \mathrm{l}$ except where indicated. 


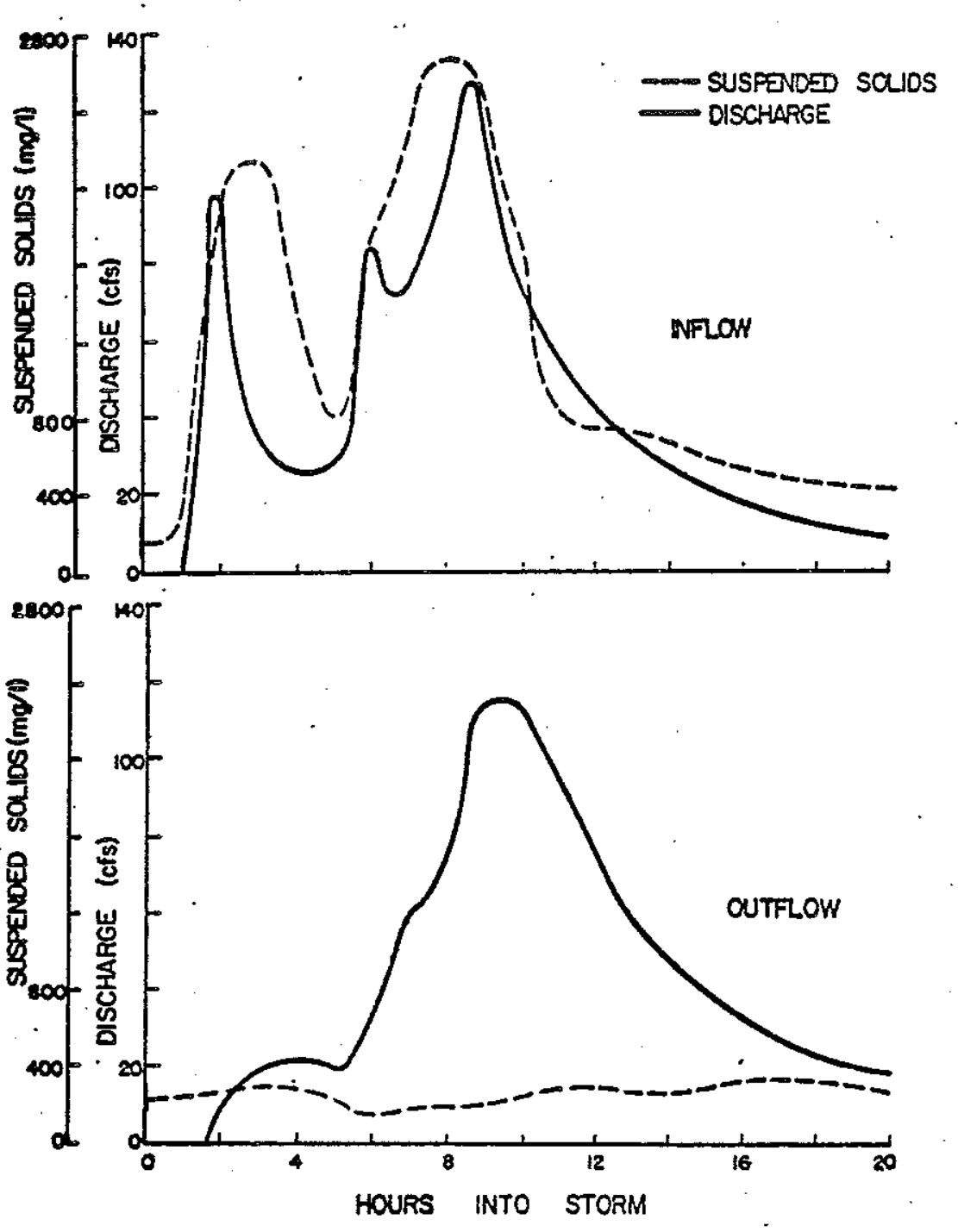

F1g. 11. Reduction of suspended solids through the woodlands lake system. 
1. D.E. Winslow, J.A. Veltman and W.H. Espey, Jr., "Natural drainage systems", presented at the Texas ASCE meeting, Beaumont, Texas, March, 1974.

2. E.V. Diniz, W.H. Espey, Jr.; W.G. Characklis, F.L. Roe and J.S. Zogorski, "Application of the storm water management model to a 'natural' drainage system in a planned community", presented at Environmental Engineering Research, Design and Development Conference, ASCE, Univ. of Florida, 1975.

3. E.V. Diniz, D.E. Holloway and W.G. Characklis, "Modelling urban runoff from a planned community", Proceedings, Conference on Environmental Modelling and Simulation, EPA, Cincinnati, Ohio, 1976.

4. W.G. Characklis, F.J. Gaudet, F.L. Roe and P.B. Bedient, "Maximum utilization of water resources in a planned community", Executive Summary Report, U.S. Environmental protection Agency, EPA \#802433, Cincinnati, Ohio, 1976.

5. C.H. Ward and J.M. King, "Eutrophication potential of surface waters in a developing community", Final Report, U.S. Environmental Protection Agency, EPA \# 802433, Cincinnati, Ohio, 1976.

6. D.A. Harned, "Stormater quality prediction utilizing loadrunoff relationships", M.S. Thesis, Rice University, 1977.

7. J. Marsalek, "Simulation of quality of urban drainage effluents", proceedings, Specialty Conference, Environmental Impact of Irrigation and Drainage, ASCE, Ottowa, Crnada, 1976.

8. Dannenbaum Engineering Corp., and Espey-Huston and Assoc., Inc. "Preliminary assessment of urban runoff impact for non-point source analysis work areawide waste treatment plan", Greater Houston Area 208 Planning Program Draft Report, HoustonGalveston Area Council, Houston, Texas, 1977.

9. E.M. Davis, "Maximum utilization of water resources in a planned community; microbiological quality of stormwater runoff in The Woodlands, Texas", Final Report, U.S.Environmental. Protection Agency, EPA \#802433, Cincinnati, Ohio, 1976. 